\title{
TRANSFORMATIVE LEADERSHIP AND ORGANIZATIONAL CULTURE EFFECT ON EMPLOYEE PERFORMANCE: EVIDENCE FROM THE INDONESIA LOGISTICS BUREAU
}

\author{
Astadi Pangarso ${ }^{1 *}$, Romat Saragih ${ }^{2}$, Waode Alaya Nuriz ${ }^{3}$ \\ 1,2,3 Telkom University, Indonesia \\ Email: ${ }^{1}$ astadipangarso@telkomuniversity.ac.id; ${ }^{2}$ saragih@telkomuniversity.ac.id; ${ }^{3}$ waodealaya@gmail.com \\ *Corresponding Author
}

\begin{abstract}
The purpose of this research was to analyze the effects of transformative leadership and organizational culture on employee performance in the context of the Indonesian Logistics Bureau. This study filled a research gap, and required repeated tests to assess the impact of transformative leadership and organizational culture on employee performance from different viewpoints. The research tool used was a cross-sectional quantitative study by a questionnaire (survey) of up to 69 respondents for all personnel of the Indonesia Logistics Bureau West Java Regional Division. Multiple linear regression analysis of data processing techniques revealed that the performance of employees was influenced by transformative leadership and organizational culture. The results of this analysis included positive guidance, in particular on the importance of a leader's role in empowering and encouraging workers through active engagement with them, and the presence of positive organization principles boosted organization performance.
\end{abstract}

Keywords: Leadership, culture, performance.

\section{Introduction}

An organization is a group of individuals who officially organize to accomplish a shared purpose (Pangarso, 2014). An essential thing related to fulfilling an organization's goals by its members is performance. Performance is still an important topic that is researched theoretically in the field of human resources, especially as an outcome of the organization.

This research can be viewed from two perspectives, namely the practical and the theoretical aspect. From the practical side, this research is essential because the Indonesia Logistics Bureau West Java Regional Division experiences problems related to performance. The Indonesia Logistics Bureau (Bulog) is a state -owned public company engaged in national food logistics. Java island is the center of Indonesia and West Java was choosen as the research location because it is the province with the greatest population in Java island (Pangarso, Astuti, Raharjo, \& Afrianty, 2020).

Indonesia Logistics Bureau performance is indicated by its rice procurement. Procurement of rice (rice is the staple food of Indonesian people) in the first quarter of 2018 reached 33,166 tons; then, in the second quarter of 2018, it increased to 130,425 tons; and in the third quarter it decreased to reach 76,425 tons. The third quarter is still classified as successful because it exceeded the target in the procurement of rice. In the fourth quarter of 2018, procurement of rice fell again, amounting to 26,727 tons. The performance of the Indonesia Logistics Bureau West Java Regional Division exhibited a tendency to decrease. Thus, the decreasing tendency of the Bureau's rice procurement capacity is the practical problem of this paper and has to be anticipated.

In general, performance, especially related to transformative leadership and organizational culture, has been widely studied. This can be seen from the results of data processing of the titles of studies using the viewer application by searching for the keywords "transformative leadership," "organizational culture", and "employee performance" on the Scopus, Crossref, and Microsoft Academic databases. Also, a literature mapping application was used through the "openknowledge maps" website using the BASE database. The results of bibliometric analysis were used by VOSviewer in Figures 1, 2 and 3 with a network production showing the relationship between the subjects. Transformative leadership, organizational culture and employee performance are related and are relevant to study from the three datasets because they have a color pattern that is not gray. Furthermore, the results of the mapping through the open knowledge maps website as shown in Figure 4 showed that the topic of this study has been quite widely researched. 


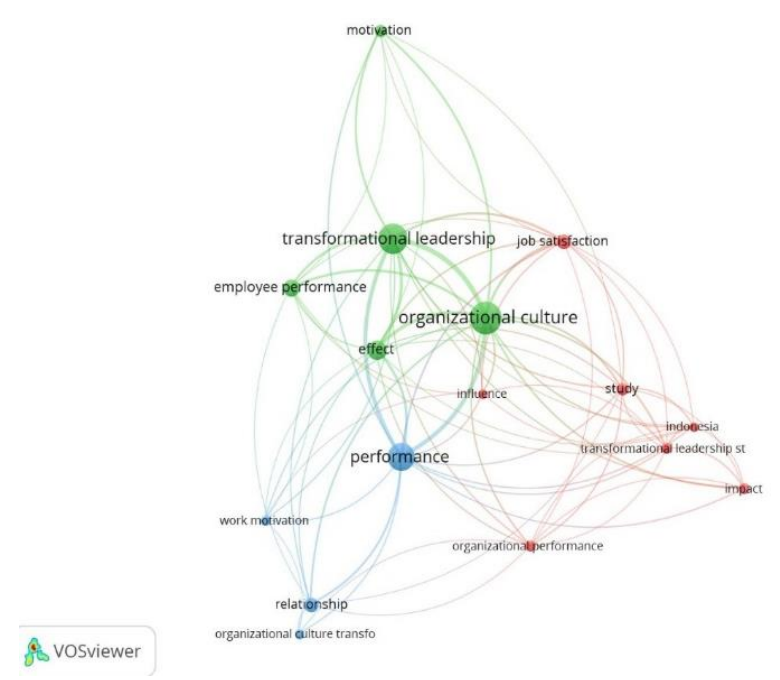

Figure 1. Network view microsoft academic database

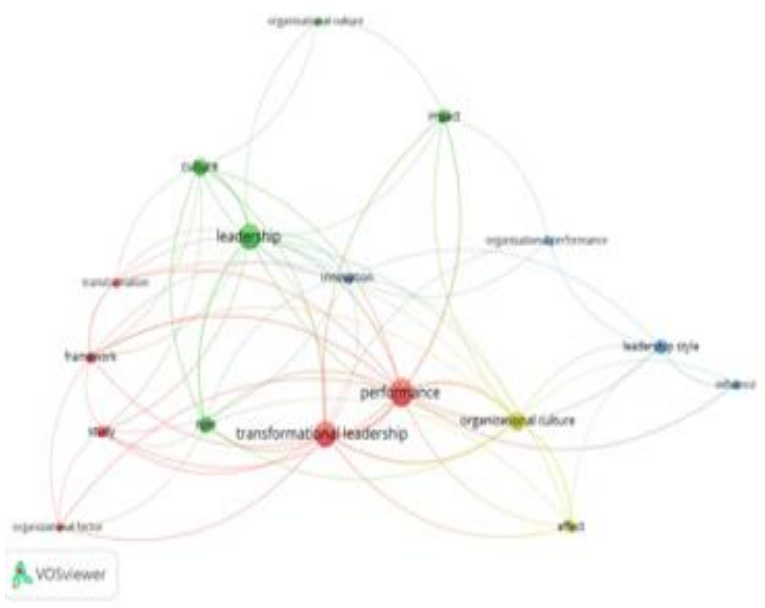

Figure 2. Network view scopus database

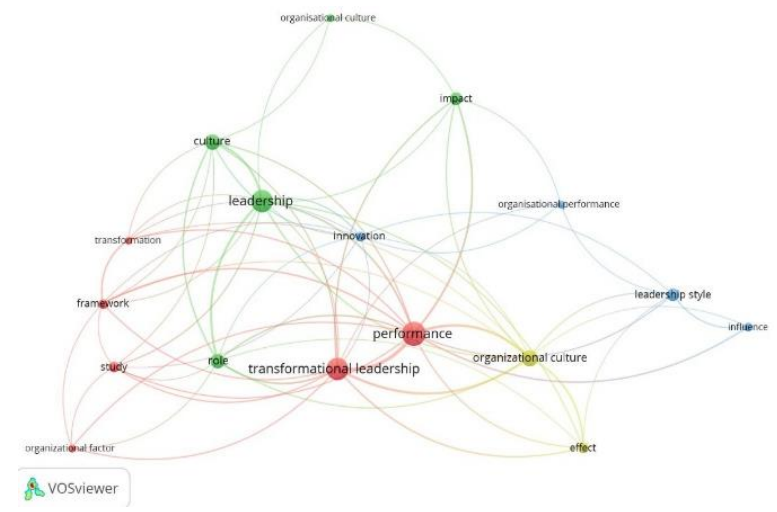

Figure 3. Network view crossref database

Theoretically, several previous studies have explored predictors of success, including transformative leadership and organizational culture, such as Mittal, Dhiman, and Lamba (2019) also Manohar, Mittal, and Marwah (2019). Transformative leadership is essential from a scientific/theoretical point of view, because it is a type of leadership that has a major influence on performance. Organizational culture is influential because the values of an organization influence the leadership style and vice versa, so it also impacts performance (Anning-Dorson, 2017; Goromonzi, 2016; Harwiki, 2016; Hiršová, Komárková, \& Pirožek, 2018; Hussein, Omar, Noordin, \& Ishak, 2016; Jogaratnam, 2017; Kumari \& Singh, 2018; Lee, Seo, Jeung, \& Kim, 2019; Maamari \& Saheb, 2018; Naranjo-Valencia, Jiménez-jiménez, \& Sanz-valle, 2016; Nazarian, Atkinson, \& Foroudi, 2017; Paais, 2018; Saad \& Abbas, 2018; Sari, Lubis, Maksum, \& Lumbanraja, 2018).

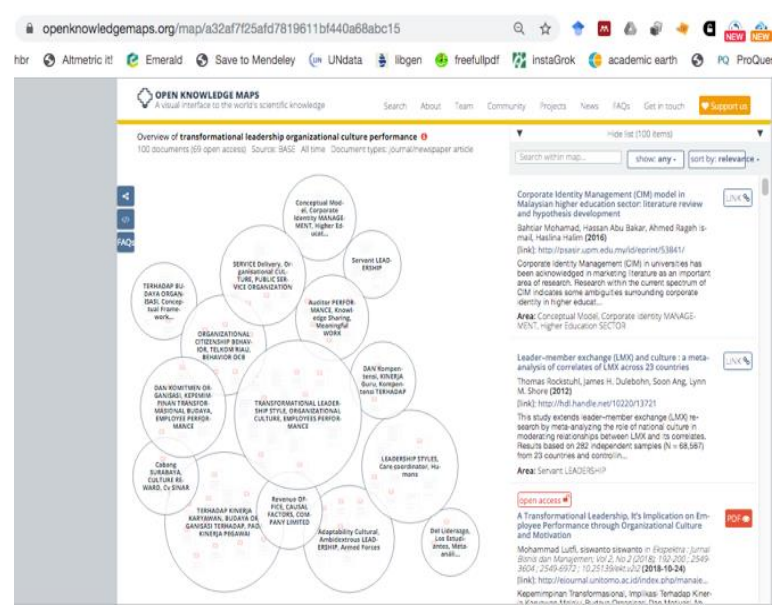

Figure 4. Open knowledge website topic mapping result

This study is interesting because few studies concurrently examine the effects of transformative leadership and organizational culture on the performance of workers in Indonesian logistics. The research problem of this study shown by previous research Harwiki (2016) and Hiršová et al. (2018) states that organizational culture does not have an important and beneficial impact on the output of employees. Also, there are still previous studies which state that the impact of transformative leadership still needs to be tested in different research contexts. Previous research fills this gap by reexamining the effect of transformative leadership and organizational culture on employee success in various contexts of the organization field, country and realistic contributions. This study raises the question, "Do transformative leadership and organizational culture still have significant impact on performance improvement?" with the research disparity discussed.

\section{Transformative Leadership}

In an organization, excellent employee performance is affected by appropriate leadership to form a harmonious bond between leaders and subordinates. If the leadership style adopted by the leader runs 
impactively, it will improve employee performance. "Leadership is a process that involves the attainment of a goal." This view describes that leadership is a process that involves the influence that occurs in a group, which is driven by the achievement of goals. That is, leadership describes the relationship between leaders and subordinates and how a leader directs subordinates. All leaders must know and understand the conditions of the organization they lead. Also, they are expected to form a harmonious and synergic communication relationship to improve employee performance.

Transformative leadership is a leadership style that refers to a dedication to the goals of the organization, giving workers trust in the attainment of outcomes that can promote positive change among their supporters. According to Bass in Darojat (2015) transformative leadership can defined as the ability of a leader to change the work environment, work motivation, performance patterns, and work values perceived by subordinates, so they can optimize their performance to achieve the goals predetermined by the organization. Darojat (2015) and Alqatawenh (2018) also said that there are five dimensions of transformative leadership behavior; namely, "Attributed Charisma" in which a leader can be a role model for his subordinates; "Idealized Influence" where the leaders try to have ideal influence on their subordinates; "Inspirational Motivation" whereby leaders inspire subordinates through motivation; and "Individualized Consideration" where the leader provides a personal attention to subordinates as much as possible.

\section{Organizational Culture}

Each organization has a characteristic that distinguishes it from other organizations; this characteristic becomes the name of the company, named organizational culture. Organizational culture refers to the distinctive associations between expectations, traditions, attitudes and ways of doing things that determine how

Table 1

Previous Research (State of The Art)

\begin{tabular}{|c|c|c|c|}
\hline References & Theory & Research context & Research location \\
\hline Pangarso, Saragih, and Al-Fath (2019) & Transformative leadership theory & Electrical Owned State Company & Indonesia \\
\hline Lee et al. (2019) & Information and decision-making theory & Multi sectors companies & Korea \\
\hline Chammas and Hernandez (2019) & $\begin{array}{l}\text { Full-range leadership theory, path-goal } \\
\text { theory }\end{array}$ & Starts up & Brazil \\
\hline Buil, Martínez, and Matute (2019) & $\begin{array}{l}\text { Social identity theory, social exchange } \\
\text { theory }\end{array}$ & Hotel & Spain \\
\hline Eliyana, Ma'arif, and Muzakki (2019) & Transformative leadership theory & Harbor & Indonesia \\
\hline Crede, Jong, and Harms (2019) & $\begin{array}{l}\text { Implicit leadership theory, transformative } \\
\text { leadership theory }\end{array}$ & Meta analysis & 34 countries \\
\hline Nam and Park (2019) & $\begin{array}{l}\text { Social-influence } \\
\text { processes }\end{array}$ & Government & South Korea \\
\hline $\begin{array}{l}\text { Kammerhoff, Lauenstein, and Schütz } \\
\text { (2019) }\end{array}$ & Transformative leadership theory & Music orchestra & Germany \\
\hline $\begin{array}{l}\text { Adriani, Joeliaty, Hilmiana, and } \\
\text { Yunizar (2019) }\end{array}$ & Transformative leadership theory & Mosque & Indonesia \\
\hline $\begin{array}{l}\text { Sinaga, Asmawi, Madhakomala, and } \\
\text { Suratman (2018) }\end{array}$ & Transformative leadership theory & PT. ATB & Indonesia \\
\hline Kumari and Singh (2018) & Organizational culture theory & \multicolumn{2}{|c|}{$\begin{array}{l}\text { Source Edge Software Technologies India } \\
\text { Pvt ltd }\end{array}$} \\
\hline Ocak and Ozturk (2018) & Transformative leadership theory & Manufacturing firms & Turkey \\
\hline Hiršová et al. (2018) & Organizational culture theory & Selected organizations & Czech Republic \\
\hline Sari et al. (2018) & Theory of the firm & The owned state companies & Indonesia \\
\hline Saad and Abbas (2018) & Organizational culture theory & Public higher education institutions & Saudi Arabia \\
\hline Paais (2018) & Organizational culture theory & Bank Maluku & Indonesia \\
\hline Maamari and Saheb (2018) & Organizational culture theory & Service firms & Middle east \\
\hline Anning-Dorson (2017) & Organizational culture theory & Service sector & Ghana \\
\hline Ariyabuddhiphongs and Kahn (2017) & Transformative leadership theory & Cafe & Thailand \\
\hline Jogaratnam (2017) & Organizational culture theory & Restaurants & US \\
\hline $\begin{array}{l}\text { Nguyen, Mia, Winata, and Chong } \\
\text { (2017) }\end{array}$ & Transformative leadership theory & Department manager & Vietnam \\
\hline $\mathrm{Ng}(2017)$ & Transformative leadership theory & Meta analysis & All over the world \\
\hline Nazarian et al.(2017) & Organizational culture theory & Hotel & UK \\
\hline Goromonzi (2016) & Organizational culture theory & Bank & Zimbabwe \\
\hline Hussein et al.(2016) & Organizational culture theory & Public higher education institutions & Malaysia \\
\hline Harwiki (2016) & Organizational culture theory & Woman cooperatives & Indonesia \\
\hline Naranjo-valencia et al. (2016) & Organizational culture theory & Agricultural sector & Spain \\
\hline Ugwu, Enwereuzor, and Orji (2016) & Transformative leadership theory & Factory workers & Nigeria \\
\hline Saragih, Pangarso and Al-fath (2020) & Transformative leadership theory & $\begin{array}{l}\text { Employees of Indonesian Electrical } \\
\text { State Owned Company }\end{array}$ & Indonesia \\
\hline
\end{tabular}


individuals and groups do things (Vaitkunaite, 2006). According to Robbins and Judge (2008), organizational culture is a mechanism that respects all organizations by common sense communicated by participants. The essence of the organizational culture is captured by seven components, including imagination, risk-taking, attention to detail, success orientation, people orientation, team orientation, violence and harmony. Siagian (2009) states that the functioning of organizational culture has a powerful positive impact on the behavior of its members, including a willingness to improve work performance.

\section{Employee Performance}

A company's output is influenced by the results of all its workers. Employee efficiency can be seen by workers' willingness to complete total duties and responsibility (Alkhamis, 2018). These tasks are usually based on items of success that have been set. Performance is a set of results achieved and refers to the act of attaining and carrying out a task in the way requested.

\section{Theoretical Framework \& Hyphoteses Development}

Over the past three years, previous studies relating to transformative leadership, organizational culture, and employee performance from reputable international scientific journal publishing databases (Science Direct, Taylor and Francis, Proquest, Ebsco) can be seen in Table 1. This table became the basis for preparing the research hypotheses.

From previous studies, the following hypotheses were prepared:

1. The direct impact of transformative leadership on performance.

According to Bangun (2012), a leader is able to influence performance in an organization. Depending on how the leader performs their leadership activities, each leader has a different leadership style and can prove that the leadership style is related to his organization's ability. It can be said that the behavior of a leader can affect employee behavior because a leader wants employees to emulate good things from themselves. The leadership style, applied to by academics, is the transformative leadership style, which is currently greatly discussed and widely researched. Previous experiments have been undertaken to investigate the major influence of transformative leadership on results (Adriani et al., 2019; Ariyabuddhiphongs \& Kahn, 2017; Buil et al. 2019; Chammas \& Hernandez, 2019; Crede et al., 2019; Eliyana et al., 2019; Kammerhoff et al., 2019; Nam \& Park,
2019; Ng, 2017; Nguyen et al., 2017; Ocak \& Ozturk, 2018; Pangarso et al., 2019; Saragih et al., 2020; Sinaga et al., 2018; Ugwu et al., 2016). Previous studies show that the effect of transformative leadership also needs to be evaluated in various study contexts (Buil et al., 2019; Crede et al., 2019; Ugwu et al., 2016). Table 1 shows previous analysis that assesses the direct effects of transformative leadership on success in a positive and drastic way.

$H_{1}$ : Based on previous research, it can be argued that transformative leadership has a strong and observable influence on success.

2. Causal influence of the atmosphere of organizations on employee results.

Previous experiments have been undertaken to determine the major influence of organizational culture on performance (Anning-Dorson, 2017; Goromonzi, 2016; Hussein et al., 2016; Jogaratnam, 2017; Kumari \& Singh, 2018; Lee et al. 2019; Maamari \& Saheb, 2018; Naranjo-valencia et al., 2016; Nazarian et al., 2017; Paais, 2018; Saad \& Abbas, 2018; Sari et al., 2018). Some previous studies still state that organizational cultural has a negative and insignificant impact on performance (Harwiki, 2016; Hiršová et al., 2018). It can be argued that business culture also has a strong and substantial effect on progress based on prior findings except the two experiments that become the research void.

$\mathrm{H}_{2}$ : Table 1 shows previous studies, which analyze the direct influence of organizational culture on outcomes positively and dramatically.

Previous studies examining the significant impact of organizational culture on performance have been carried out (Nam \& Park, 2019; Sinaga et al., 2018). The theoretical structure of this research can be seen in Figure 5.

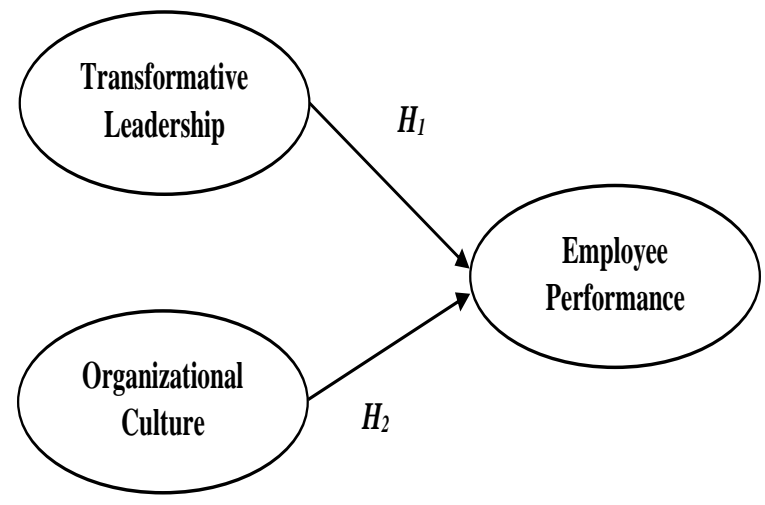

Figure 5. Theoretical framework 


\section{Research Method}

This empirical investigation is a basic and crosssectional quantitative study that collected data through a survey. A total of 45 questionnaire items represented the variables: transformative leadership adopted from Darojat (2015) consisted of 18 items; organizational culture adopted from Robbins and Judge (2008) consisted of 15 items; and employee performance adopted from Kasmir (2016) consisted of 12 items. The instruments adopted from Darojat (2015) for transformative leadership; Robbins and Judge (2008) for organizational culture and Kasmir (2016) for employee performance present research phenomena, and have been widely used in related reserch fields. The items used the Likert scale for a scale of $1-5$ questionnaire statements (strongly disagree to strongly agree).

The unit of analysis of this research is the individual. Non-probability sampling using the whole population in a survey was the sampling approach used (saturated sample). The study population was all West Java employees in the Regional Logistics Bureau Division, which amounted to a total of 69 respondents. After the questionnaires were collected, the validity and reliability of the data were checked. Once the data was proven to be both valid and reliable, the data was analyzed using multiple linear regression techniques.

\section{Result and Discussion}

The response rate of the questionnaire distributed was $100 \%$; that is, from the 69 questionnaires distributed, all 69 were eligible for further testing. The demographic profiles of the respondents are collected in Table 2.

Table 2

The Demographic Profile of the Respondents

\begin{tabular}{llc}
\hline Profile & Sub profile & Percentage (\%) \\
\hline Gender & Man & 56 \\
& Woman & 44 \\
Age & Below 20 & 13 \\
& $20-40$ & 67 \\
\multirow{5}{*}{ Education } & Above 40 & 20 \\
Background & High school & 13 \\
& Diploma & 31 \\
& Undergraduate & 49 \\
\multirow{3}{*}{ Work Experience } & Postgraduate & 7 \\
& Less than five years & 45 \\
& 5-10 years & 36 \\
& More than ten years & 19 \\
\hline
\end{tabular}

After the data was collected, it was checked using validity and reliability tests. As the value of total correlation score of each item was more than the $R$-table value, it was concluded that all items of the research questionnaire are valid. Cronbach's alpha coefficient was used for reliability analysis, and the cut off value of $R$-count had to be more than 0.700 (0.757). So, it is concluded that all item instruments were reliable.

The next step involved multiple regression consisting of a sequence of processes: normality test, heteroscedasticity test, multi regression linear, $t$-test, $F$-test, and determination coefficient. Data normality can be seen in various ways; one of the methods used was the Histogram displaying a normal curve method and a PPLOT curve with decision-making criteria.

a) If the data spreads along the diagonal line and follows the diagonal line path or a standard distribution pattern is shown in the histogram graph, then the regression model meets the classical assumptions.

b) If the data does not scatter along the diagonal line and does not obey the direction of the diagonal line, or a standard distribution pattern is not shown in the histogram graph, then model of regression does not fulfill the classical assumptions. The data normality test is shown in Figure 6 and Table 3.

Table 3

Kolmogorov-smirnov Test

\begin{tabular}{llc}
\hline & & $\begin{array}{c}\text { Unstandarized } \\
\text { Residual }\end{array}$ \\
\hline$N$ & & 69.000 \\
Normal Parameters & Mean & 0.000 \\
& Std.Deviation & 0.190 \\
Most Extreme & Absolute & 0.063 \\
Differences & & \\
& Positive & 0.063 \\
Test Statistic & Negative & 0.063 \\
$\begin{array}{l}\text { Asymp. Sig. (2- } \\
\text { tailed) }\end{array}$ & & 0.063 \\
\hline
\end{tabular}

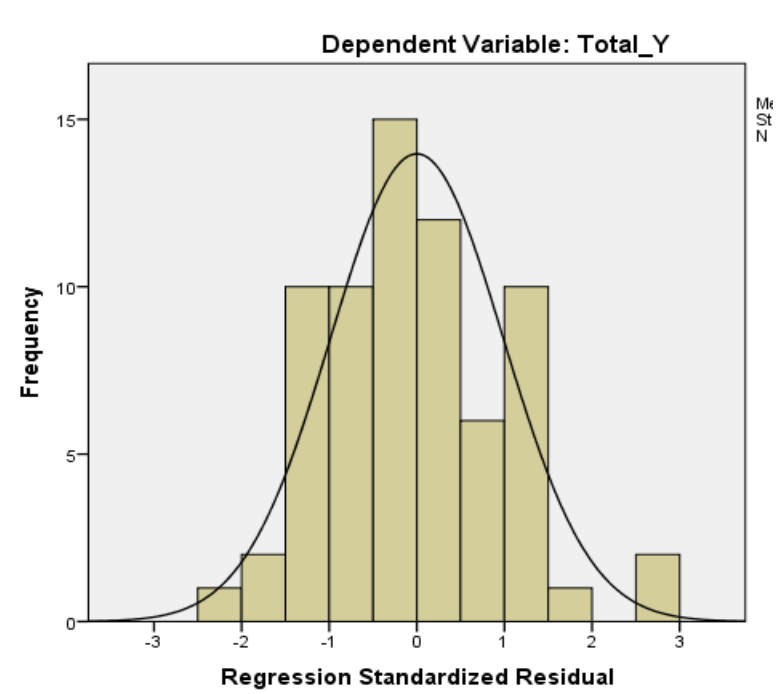

Figure 6. Normality test results on the histogram

Mean $=2.62 \mathrm{E}-15$

Std. Dev. $=0.985$

$\mathrm{N} \quad=69$

(Total_Y: Employee Performance) 
Based on Figure 6, it can be assumed that the entire dataset used to calculate the employee performance variable passed the normality test. It can be seen in lines forming bells or symmetrical curves. The normality test results in Figure 6 indicate that the overall data used to measure employee performance variables is normally distributed. Also, the results of the normality test data indicate a substantially higher value than alpha, based on Table $4(0.200>0.050)$. Therefore, it can be concluded that the data of all variables has a normal distribution.

In addition, to ensure that a normality test can be conducted with Kolmogorov-Smirnov (K-S) with a relevant level (alpha) of 0.050 in addition to the use of the P-P plot. With the parameters:

1) If the value of Asymp. Sig. Sec. (2-tailed) > 0.050, there is no natural distribution disturbance in the data.

2) If the value of Asymp. Sig. Sec. (2-tailed) < 0.050, then the data suffered a normal disturbance in the distribution.

To see if there is an inequality of variance from residual variables to other variables, the heteroscedasticity test was used. Heteroscedasticity is not a positive regression model (Indrawati, 2015). According to Ghozali (in Atmaja, 2011), the framework for decision making is:

1) If a regular pattern is created by specific patterns, such as points (wavy, expanded, and then narrowed), then heteroscedasticity occurs.

2) If there is no simple trend and the points on the $Y$ axis scatter above and below the number 0 , heteroscedasticity is not present.

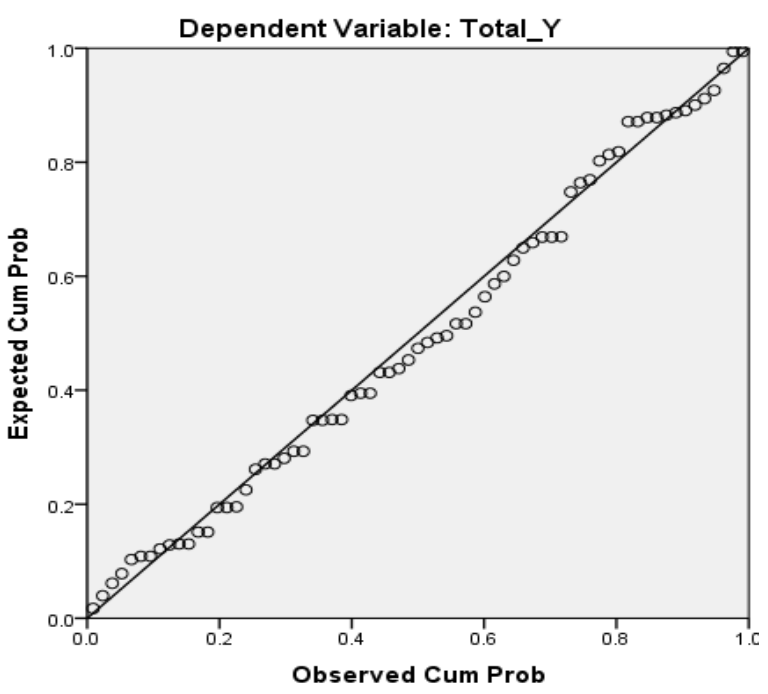

Figure 7. P-P plot data normality test

(Total_Y: Employee Performance)

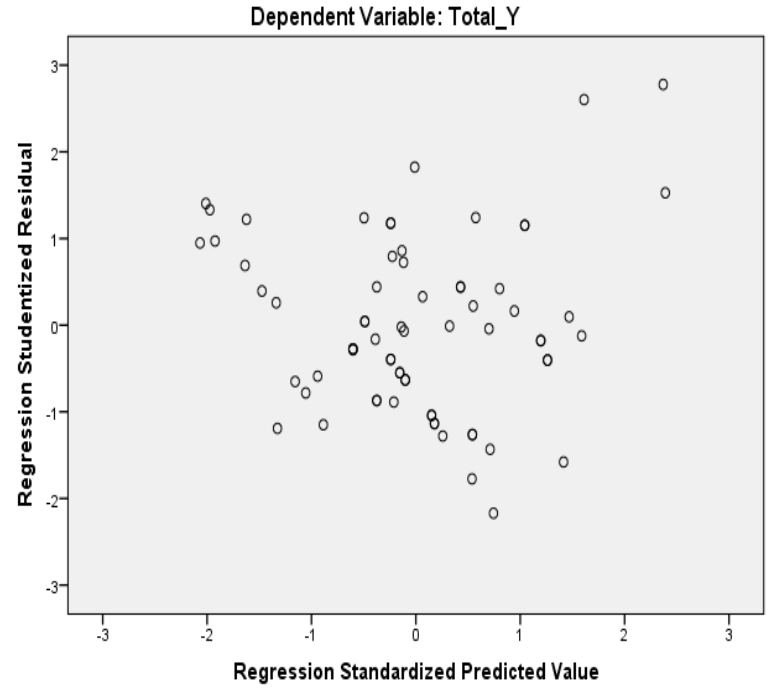

Figure 8. Diagram scatterplot

(Total_Y: Employee Performance)

Table 4

Multi Linear Regression and $t$-test

\begin{tabular}{|c|c|c|c|c|c|c|c|}
\hline \multirow[t]{2}{*}{ Model } & \multirow{2}{*}{\multicolumn{3}{|c|}{$\begin{array}{l}\text { Unstandarized Coefficients } \\
\text { Standarized Coefficients }\end{array}$}} & \multirow[t]{2}{*}{$T$} & \multirow[t]{2}{*}{ Sig. } & \multicolumn{2}{|c|}{$\begin{array}{l}\text { Collinearity } \\
\text { Statistics }\end{array}$} \\
\hline & & & & & & Tolerance & VIF \\
\hline 1 (Constant) & 1.126 & 0.157 & & 7.178 & 0.000 & & \\
\hline Total_ $\boldsymbol{X}_{\boldsymbol{I}}$ & 0.482 & 0.075 & 0.648 & 6.394 & 0.000 & 0.355 & 2.818 \\
\hline Total_ $\boldsymbol{X}_{2}$ & 0.183 & 0.071 & 0.261 & 2.572 & 0.012 & 0.355 & 2.818 \\
\hline
\end{tabular}

Figure 8 shows that either at the top of the zero or at the bottom of the vertical axis zero or the $Y$-axis (divided by four quadrants), the data distribution map does not form special patterns or randomly distributed points; thus, it can be inferred that there are no heteroscedasticity markers in this regression model.

The regression coefficient is obtained based on Table 4 performance, so that the equation is as follows: $Y=1.126+0.482 X_{I}+0.183 X_{2}$

The following can be seen from the multiple linear regression equation:

a) A constant value of 1.126 suggests that the value of employee performance $(Y)$ is equal to 1.126 if there is no influence from transformative leadership $\left(X_{I}\right)$ and organizational culture $\left(X_{2}\right)$.

b) The 0.482 regression coefficient value of $X_{l}$ (transformative leadership) means that if $X_{l}$ increases by one unit, it will change employee output by 0.482 units, provided that all factors are called constant.

c) The $X_{2}$ (organizational culture) regression coefficient is 0.183 , which means that if $X_{2}$ increases by one unit, it will influence the output of workers by 0.183 units, given that all variables are considered stable. 
Studies have found that transformative leadership and organizational culture have a positive effect on employee success based on these equations.

The Indonesia Logistics Bureau West Java Regional Office uses partial hypothesis testing or T-tests to partly analyze the impact of disruptive leadership and organizational culture on employee performance. The effect of the independent variables was evaluated with a probability value of alpha $=0.050 \%$ on the dependent variable. The hypothesis which will be partially tested is:

1) $H_{0}: \rho_{1}=0$

Meaning: Transformative leadership at the Indonesia Logistics Bureau Regional West Java office has no major effect on employee results.

$H_{a}: \rho_{l} \neq 0$

Meaning: Transformative leadership has a major influence on employee outcomes at the Indonesia Logistics Bureau Regional West Java branch.

2) $H_{0}: \rho_{2}=0$

Meaning: In the Indonesia Logistics Bureau Regional West Java office, the organizational culture has no major effect on employee efficiency. $H_{a}: \rho_{2} \neq 0$

Meaning: The organizational atmosphere has a huge influence on employee productivity at the Indonesia Logistics Bureau Regional West Java Regional Office.

The acceptance or denial criteria for the theory are as follows:

1) If the $t$-count is greater than 0.050 , then $H_{0}$ is acknowledged and $H_{a}$ is rejected, showing that there is no significant influence of the dependent variable between the independent variables.

2) If the t-table measurement and the significance value are less than $0.050, H_{0}$ is denied and $H_{a}$ is accepted, meaning that the dependent variable has a substantial effect on the independent variables. In order to define the value of the table $t$, the formula must have a degree of independence:

a) Degrees of freedom $(d f)=(n-k)$ and accuracy standard $(\alpha)=5 \%$

b) $N=$ quantity of samples, $n=69$

c) $K=$ quantity of variables, $k=3$

The degrees of freedom, then is $(d f)=n-k=69-3=$ 66. A two-way test was the $t$-test used, then the t-table used was $t 0.050(66)=1.668$. It can be shown, based on Table 4, that:

1) At the estimation value (6.394) $>$ t-table (1.668) and a significance level of $0.000<0.050$, the transformative leadership component $\left(X_{I}\right)$ has a value of
$H_{0} . H_{0}$ is dismissed. It can then be concluded that the transformative leadership variable $\left(X_{l}\right)$ has a major influence on employee success $(Y)$ and that hypothesis 1 is acknowledged.

2) The community of the vector organization $\left(X_{2}\right)$ has a $t$-count (2.572) $>t$-table (1.668) and a degree of significance of $0.012<0.050 ; H_{0}$ is then denied. Therefore, it can also be inferred that variables $(Y)$ have a major impact on employee success in the organizational culture $\left(X_{2}\right)$, hypothesis 2 is known.

The coefficient of determination $(K D)$ or the value of $R$-square $\left(R^{2}\right)$ used to assess how much impact leadership - the input of the independent variable $\left(X_{I}\right)$ and organizational culture - the independent variable $\left(X_{2}\right)$ - have on the dependent variable $(Y)$ - that is, the output of the employee. The calculation of the determination coefficient was performed using SPSS, which can be seen in Table 5 .

Table 5

Coefficient Determination

\begin{tabular}{ccccc}
\hline Model & $\boldsymbol{R}$ & $\boldsymbol{R}$-square & $\begin{array}{c}\text { Adjusted } \\
\boldsymbol{R} \text {-square }\end{array}$ & $\begin{array}{c}\text { Std. Error of the } \\
\text { Estimate }\end{array}$ \\
\hline 1 & 0.871 & 0.759 & 0.752 & 0.193 \\
\hline
\end{tabular}

Table 5 demonstrates the extent of the effect of transformative leadership and organizational culture on employee morale at the Indonesia Regional West Java Logistics Bureau office. The determination coefficient or the $R$-square value showed that with this formula, the magnitude effect:

$K D=r^{2} \times 100 \%=(0.871)^{2} \times 100 \%=75.900 \%$

A significance of 75.900 percent means that transformative leadership and organizational culture variables impact 75.900 percent of employee success variables, while other variables not evaluated in this study influence the remaining 24.100 percent. This reveals a gap in the literature, potentially indicating a need to explore other variables beyond transformative leadership and organizational culture in future research, e.g., organizational agility.

A theoretical contribution and a practical contribution are the results of this research study. The theoretical contribution supports transformative leadership theory and organization theory, both of which contribute to the important effect of transformative leadership and organizational culture on enhancing employee performance. Furthermore, the findings of this study support previous studies regarding the positive and concrete impact on employee performance of transformative leadership, as can be seen in Table 1 .

Previous findings by Adriani et al. (2019), Ariyabuddhiphongs and Kahn (2017), Buil et al. (2019), 
Chammas and Hernandez (2019), Crede et al. (2019), Eliyana et al. (2019), Kammerhoff et al. (2019), Nam and Park (2019), Ng (2017), Nguyen et al. (2017), Ocak and Ozturk (2018), Sinaga et al. (2018), Ugwu et al. (2016), and Saragih et al. (2020). The major effect of organizational culture on employee success confirms previous research conducted by Anning-Dorson (2017), Goromonzi (2016), Hussein et al. (2016). Jogaratnam (2017), Kumari and Singh (2018), Lee et al. (2019), Maamari and Saheb (2018), Naranjo-valencia et al. (2016), Nazarian et al. (2017), Paais (2018), Saad and Abbas (2018), and Sari et al. (2018). Around the same time, previous findings by Nam and Park (2019), Sinaga et al. (2018), Biswas (2013), and Xenikou and Simosi (2006) supported the important impact of transformative leadership and organizational culture on employee success. The findings of the current study potentially prove that transformative leadership and organizational culture also have a partial influence on employee success in Indonesia's food supply industry at the same time.

From Table 2, the demographic profiles of the respondents can be analyzed as follows. Age has a relationship with work performance and employee performance. More specifically, the age factor refers to several positive qualities that older workers bring to their work, especially experience, a robust work ethic, and a commitment to excellence. With a composition of as much as $80 \%$ of employees under 40 years, the age of employees is quite ideal for carrying out tasks assigned to the Indonesia Logistics Bureau Regional Division West Java office.

Various psychological studies show that women are more willing to adjust to authority, while men are more aggressive and are more likely to be successful than women. Still, the difference in comparison is sma11 , so it depends on research conducted by researchers whether dominated by men or women. This means that companies need more male employees to work aggressively to learn new things at work; on the other hand, companies also need female employees to be able to adjust to the work environment (Robbins \& Judge, 2008).

According to Hartatik (2014), in the process of acquiring and enhancing the standard of individual professional skills, education plays a vital role. This means that employees who have a high level of education are more qualified and professional at work based on educational background data, at the Indonesia Logistics Bureau Regional Division of West Java, the employees were spread across three groups - S1, S2, and S3 education groups with a total of $56 \%$.
An extended work period at a company would make an employee feel more at home or tend to have a sense of work attachment because they have been working there long enough to adapt to the work environment and feel comfortable with their work. Data shows that $55 \%$ of the Indonesia Logistics Bureau Regional Division of West Java office employees have more than five years of work experience. Thus, the Indonesia Logistics Bureau Regional Division of West Java office employees has a workforce with long work experience.

The practical contribution of this study is to urge the management of the Indonesian Logistics Bureau's West Java Regional Division to pay heed to the value of transformative leadership and organizational culture to boost employee productivity. By focusing on three aspects, this study will add value to the overall management of the company: leaders must empower and encourage their subordinates; the strategic value and emphasis on organization success must be included in the organizational culture. If the company can build a leader with the attributes of a transformative leader, this would have an effect on improving employee performance. Leaders that can empower and encourage their subordinates by engaging and working with them have the highest correlation value of transformative leadership variables $\left(X_{I} \_7\right)$. Things that need to be considered to shape a person into a transformative leader include: leadership training, implementing a 360-degree leadership assessment system in the organization, implementing awards for outstanding leaders, and showing active participation in working with subordinates.

Furthermore, in terms of organizational culture, it can be seen that the item that has the highest correlation with organizational culture variables is the existence of organization values related to aggressiveness to compete $\left(X_{2} \_12\right)$. To increase the competitiveness within the organization, the company can hold competitions and give awards related to employee work performance. Of course, the culture of competition in organizations must also pay attention to the balance in terms of collaboration. If an organization has values to compete aggressively, the organization can compete better.

An important item of employee performance with the highest correlation value is efficiency in terms of the use of organizational resources $\left(Y_{8}\right)$. Therefore, if the leader of the organization can motivate and inspire employees through active engagement with them and the organizational culture encourages competition, organizational efficiency will increase. Organizational resources can be grouped into tangible and intangible, as well as financial and non-financial. The results of this study highlight that efficiency is important for the performance of an organization. 


\section{Conclusions and Implications}

In the background of the Indonesia Division of the West Java Regional Logistics Bureau, transformative leadership and organizational culture have a significant influence on the effectiveness of its workers . This study emphasizes and supports the philosophy of transformative leadership and organization strategy, which notes that transformative leadership and organizational culture have a major effect on the development of employee productivity. Considering the key problems of the West Java Regional Logistics Bureau of Indonesia, this study is strategically useful in terms of decision-making related to optimizing employee efficiency by transformative leadership and organizational culture. The results of this analysis include positive guidance, in particular on the importance of a leader's role in empowering and encouraging workers through active engagement with them, and the presence of positive organizational principles can boost organization performance.

The drawbacks of this research are that the study was conducted in a very restricted context with a limited number of tests, focused only on the idea of transformative leadership and organizational culture, and performed under a timeline setting (cross-sectional). For further future research, the scope of the study could be expanded to include a range of countries (not only analysis of one province) that could later be linked to the role of the owned state company in food security sector in Indonesia, and also in a longitudinal research to realize the Golden Indonesia 2045. The Logistics Bureau of Indonesia plays an important role as it supplies a main human need, which is rice as Indonesians' basic food. So the quantity supply of rice would be play an important role to support Indonesian to realize Golden Indonesia 2045 as a country. Indonesia have a big opportunity to become a developed country in 2045 when the goals of the Golden Indonesia vision are reached (Pangarso et al., 2020). It is also advisable to examine other leadership concepts that are hot topics, such as transcendental leadership.

\section{References}

Adriani, Z., Joeliaty, Hilmiana, \& Yunizar (2019). Improving performance through transformative leadership and utilization of information technology: A survey in mosque-based Islamic cooperatives in Indonesia. Academy of Strategic Management Journal, 18(2), 1-14

Alkhamis, F. A. (2018). The mediating role of employee job performance in the impact of open book management dimensions on customer satisfaction. Business: Theory and Practice, 19, 157-165. https://doi.org/10.3846/btp.201 8.16
Alqatawenh, A. S. (2018). Transformative leadership style and its relationship with change management. Business: Theory and Practice, 19, 17-24. https://doi.org/10.3846/btp.2 018.03

Anning-Dorson, T. (2017). Moderation-mediation effect of market demand and organizational culture on innovation and performance relationship. Marketing Intelligence and Planning, 35(2), 222-242. https://doi.org/10.11 08/MIP-04-20160066

Ariyabuddhiphongs, V., \& Kahn, S. I. (2017). Transformative leadership and turnover intention: The mediating effects of trust and job performance on café employees in Thailand. Journal of Human Resources in Hospitality and Tourism, 16(2), 215-233. https://doi.org/10.1080/15332845.2016. 1202730

Atmaja, A. E. (2011). Analisis faktor-faktor yang mempengaruhi pendapatan asli daerah di Semarang. Skripsi. Universitas Negeri Semarang.

Bangun, W. (2012). Manajemen sumber daya manusia. Bandung: PT. Erlangga.

Biswas, S. (2013). Organizational culture \& transformative leadership as predictors of employee performance. Indian Journal of Industrial Relations, 44(4), 611-627.

Buil, I., Martínez, E., \& Matute, J. (2019). Transformative leadership and employee performance: The role of identification, engagement and proactive personality. International Journal of Hospitality Management, 77(October 2017), 64 75. https://doi.org/10.1016/j.ij hm.2018.06.014

Chammas, C. B., \& Hernandez, J. M. da C. (2019). Comparing transformative and instrumental leadership. Innovation \& Management Review, 16(2), 143-160. https://doi.org/10.1108/inmr-082018-0064

Crede, M., Jong, J., \& Harms, P. (2019). The generalizability of transformative leadership across cultures: A meta-analysis. Journal of Managerial Psychology, 34(3), 139-155. https://doi.org/10. 1108/JMP-11-2018-0506

Darojat, T. A. (2015). Pentingnya budaya kerja tinggi dan budaya kerja kuat. Bandung: PT Refika Aditama.

Eliyana, A., Ma'arif, S., \& Muzakki (2019). Job satisfaction and organization commitment effect in the transformative leadership towards employee performance. European Research on Management and Business Economics, 25(3), 144-150. https://doi.org/10.1016/j.iedeen.2019. 05.001

Goromonzi, W. O. (2016). Organizational culture, strategy implementation and commercial bank 
performance in Zimbabwe. International Review of Management and Marketing, 6(2), 307-316.

Hartatik, I. P. (2014). Buku praktis mengembangkan SDM. Jogjakarta: Laksana.

Harwiki, W. (2016). The impact of servant leadership on organizational culture, organization commitment, organization citizenship behaviour (OCB) and employee performance in women cooperatives. Procedia - Social and Behavioral Sciences, 219, 283-290. https://doi.org/10.1016/j.sbspro. 2016.04.032.

Hiršová, M., Komárková, L., \& Pirožek, P. (2018). The prediction of financial performance in dependence on the type of organisational culture. Trends Economics and Management, 12(32), 63. https://doi.org/10.13164/ trends.2018.32.63.

Hussein, N., Omar, S., Noordin, F., \& Ishak, N. A. (2016). Learning organizational culture, organization performance and organization innovativeness in a public institution of higher education in Malaysia: A preliminary study. Procedia Economics and Finance, 37 (16), 512-519. https://doi.org/10.1016/s2212 -5671(16)30159-9

Indrawati. (2015). Metode penelitian manajemen dan bisnis: Konvergensi, teknologi komunikasi dan informasi. Bandung: Refika Aditama.

Jogaratnam, G. (2017). How organizational culture influences market orientation and business performance in the restaurant industry. Journal of Hospitality and Tourism Management, 31, 211219. https://doi.org/10.1016/j.jhtm. 2017.03.002

Kammerhoff, J., Lauenstein, O., \& Schütz, A. (2019). Leading toward harmony-Different types of conflict mediate how followers' perceptions of transformative leadership are related to job satisfaction and performance. European Management Journal, 37(2), 210-221. https://doi.org/10.1016/ j.emj.2018.06.0 03 .

Kasmir. (2016) Manajemen sumber daya manusia (Teori dan praktik). Depok: PT. Rajagrafindo Persada.

Kumari, N., \& Singh, D. (2018). Impact of organizational culture on employee performance. Prabandhan: Indian Journal of Management, 11(6), 53-63. https://doi.org/10.17010/pijom/ 2018/v11i6/128442.

Lee, J. Y., Seo, Y., Jeung, W., \& Kim, J. H. (2019). How ambidextrous organizational culture affects job performance: A multilevel study of the mediating effect of psychological capital. Journal of Management and Organization, 25(6), 860875. https://doi.org/1 0.1017/jmo.2017.38.
Maamari, B. E., \& Saheb, A. (2018). How organizational culture and leadership style affect employees' performance of genders. International Journal of Organization Analysis, 26 (4), 630 651. https://doi.org/10.1108/IJOA-04-2017-1151

Manohar, S., Mittal, A., \& Marwah, S. (2019). Service innovation, organizational reputation and wordof-mouth in the banking sector: A test on multigroup-moderated mediation effect. Benchmarking, 27(1), 406-429. https://doi.org/10.1108/ BIJ-05-2019-0217.

Mittal, A., Dhiman, R., \& Lamba, P. (2019). Skill mapping for blue-collar employees and organisational performance: A qualitative assessment. Benchmarking: An International Journal, 26(4), 12551274. https://doi.org/10.11 08/BIJ-08-2018-0228

Nam, K. A., \& Park, S. (2019). Factors influencing job performance: Organization learning culture, cultural intelligence, and transformative leadership. Performance Improvement Quarterly, 32(2), 137-158. https://doi.org/10.1002/piq.21292

Naranjo-valencia, J. C., Jiménez-jiménez, D., \& Sanzvalle, R. (2016). Studying the link between organizational culture, innovation and performance in Spanish companies. Revista Latinoamericana de Psicologia, 30-41. https://doi.org/ 10.1016/j.rlp.2015.09.009.

Nazarian, A., Atkinson, P., \& Foroudi, P. (2017). Influence of national culture and balanced organizational culture on the hotel industry's performance. International Journal of Hospitality Management, 63, 22-32. https://doi.org/10.1016/ j.ijhm.2017.01.003.

Ng, T. W. H. (2017). Transformative leadership and performance outcomes: Analyses of multiple mediation pathways. Leadership Quarterly, 28(3), 385-417. https://doi.org/10.101 6/j.leaqua. 2016.11.008.

Nguyen, T. T., Mia, L., Winata, L., \& Chong, V. K. (2017). Effect of transformative-leadership style and management control system on managerial performance. Journal of Business Research, 70, 202-213. https://doi.org/10.1016/j.jbusres.2016. 08.018.

Ocak, M., \& Ozturk, A. (2018). The role of transformative leadership behaviours' effects on organizational entrepreneurship behaviours and financial performance of firms. International Review of Management and Marketing, 8(4), 4555.

Paais, M. (2018). Effect of work stress, organizational culture and job satisfaction toward employee performance in Bank Maluku. Academy of Strategic Management Journal, 17(5), 1-13. 
Pangarso, A. (2014). Organization's structure based on competing value approach and merger strategy. Proceedings of $20142^{\text {nd }}$ International Conference on Technology, Informatics, Management, Engineering and Environment, TIME-E 2014. https://doi.org/10.1109/TIME-E.2014.70 11616.

Pangarso, A., Astuti, E. S., Raharjo, K., \& Afrianty, T. W. (2020). The impact of absorptive capacity and innovation ambidexterity on sustainable competitive advantage: The case of Indonesian higher education. Entrepreneurship and Sustainability Issues, 7(3), 2436-2455. https://doi.org/10.9770/ jesi.2020.7.3(6 5).

Pangarso, A., Saragih, R., \& Al-Fath, M. R. (2019). Are transformational leadership and work motivation still affecting employee performance? (Evidence from Indonesian electrical owned state company). Advance. Preprint. https://doi.org/10. 31124/advance.9756 584.v1.

Robbins, S. P., \& Judge, T. A. (2008). Perilaku organisasi. Edisi ke-12. Jakarta: Salemba Empat

Saad, G. B. \& Abbas, M. (2018). The impact of organizational culture on job performance: A study of Saudi Arabian public sector work culture. Problems and Perspectives in Management, 16(3), 207-218. https://doi.org/10.2 1511/ppm.16(3).2018.17.

Saragih, R., Pangarso, A., Al-fath, M. R., \& Java, W. (2020). Does transformative leadership and work motivation still affect employee performance? Evidence from an Indonesian electrical state owned company. International Journal of Innovation, Creativity and Change, 14(3), 1096-1117
Sari, M., Lubis, A. de F., Maksum, A., \& Lumbanraja, P. (2018). The influence of organization's culture and internal control to organizational governance and is impact on bumn (State-owned enterprises) organizational performance in Indonesia. Journal of Advanced Research in Law and Economics, 9(2), 681-691. https://doi.org/10.14505/jarle.v92 (32).30.

Siagian, S. P. (2009). Kiat meningkatkan produktivitas kerja. Jakarta. PT. Rineka Cipta.

Sinaga, H. G., Asmawi, M., Madhakomala, R., \& Suratman, A. (2018). Effect of change in management, organizational culture and transformative leadership on employee performance PT. Adhya Tirta Batam (PT. ATB). International Review of Management and Marketing, 8(6), 1523.

Ugwu, L. I., Ewereuzor, I. K., \& Orji, E. U. (2016). Is trust in leadership a mediator between transformative leadership and in-role performance among small-scale factory workers? Review of Managerial Science, 10(4), 629-648. https://doi.org/10.1007/s11846-01 5-0170-z

Vaitkunaite, V. (2006). The impact of merged organiztions culture on enterprise success. Business: Theory and Practice, 7(1), 45-53. https://doi. org/10.3846/btp.2006.07.

Xenikou, A., \& Simosi, M. (2006). Organizational culture and transformative leadership as predictors of business unit performance. Journal of Managerial Psychology, 21(6), 566-579. https://doi.org/10.1108/0268394061068 4409. 